\title{
Who cares about the lobbying agenda?
}

\author{
David C. Kimball ${ }^{\mathrm{a}, *}$, Frank R. Baumgartner ${ }^{\mathrm{b}}$, Jeffrey M. Berry ${ }^{\mathrm{c}}$, \\ Marie Hojnacki ${ }^{\mathrm{d}}$, Beth L. Leech ${ }^{\mathrm{e}}$ and Bryce Summary ${ }^{\mathrm{a}}$ \\ ${ }^{a}$ Department of Political Science, University of Missouri-St. Louis, One University Blvd., 347 SSB, \\ St Louis, MO 63121-4499, USA. \\ ${ }^{\mathrm{b}}$ Department of Political Science, University of North Carolina, Campus Box 3265, Chapel Hill, \\ NC 27599-3265, USA. \\ ${ }^{\mathrm{c}}$ Department of Political Science, Tufts University, Packard Hall, Medford, MA 02155, USA. \\ ${ }^{\mathrm{d}}$ Department of Political Science, Penn State University, 213 Pond Lab, University Park, \\ PA 16802-6200, USA. \\ ${ }^{\mathrm{e}}$ Department of Political Science, Rutgers University, 89 George Street, New Brunswick, NJ 08901, \\ USA. \\ *Corresponding author.
}

Executive Summary There has been a long-standing concern about inequality in the representation of interests by organized groups and lobbyists in American politics. The lobbying community in Washington is dominated by corporations, trade associations and professional associations. In Lobbying and Policy Change, Baumgartner and colleagues find that interest group resources are not a very reliable predictor of policy outcomes. This might lead some to conclude that inequality in interest group representation is not a major problem for American democracy. However, we suggest that inequality in interest group representation presents itself at the agenda-setting stage. The public agenda is quite different from the lobbying agenda. That is, the types of issues that are most important to the public differ from the types of issues that lobbyists bring to the attention of government officials. We examine public opinion data in more detail to determine if there is greater congruence between the public agenda and lobbying agenda for certain publics (for example, high SES citizens). We find additional evidence that the lobbying agenda does not reflect the policy priorities of the public. However, we find relatively few differences between the policy priorities of low-income and highincome Americans, suggesting that the lobbying agenda fails to represent the concerns of all broadly defined income groups.

Interest Groups \& Advocacy (2012) 1, 5-25. doi:10.1057/iga.2012.7;

published online 20 March 2012

Keywords: lobbying; policy agenda; interest groups; political inequality; representation 
Whose interests are represented when public policy is made in the United States? This is a fundamental question in American political science, and it has received renewed attention given increasing levels of economic inequality (Picketty and Saez, 2003; Jacobs and Skocpol, 2005; Bartels, 2008; Kelly, 2009). Several recent studies examine the correspondence between the policy preferences of the public and policy positions or outputs produced by government. In addition, some studies analyze policy representation of different citizen subgroups (often defined by income level).

Although policy preferences are a critical element in studies of political representation, we argue that they are not the only way to examine the links between citizen interests and government behavior. Consideration should also be given to the policy agenda in Washington and the degree to which it reflects the priorities of the public. Furthermore, some of the recent work gives scant attention to the role of interest groups in the study of representation in the policy process.

In this article, we review some of the conflicting findings in recent research on policy representation and we make the case for including interest groups and the policy agenda in the study of representation. Continuing earlier work, we use several data sources to compare a representative set of issues being lobbied in Washington (the lobbying agenda) with the policy domains deemed most important by the public (the public agenda). We find that the lobbying agenda bears no resemblance to the policy priorities of the public, regardless of which measure of public opinion is used. When we scrutinize public concerns and lobbying issues within the same policy domain, we find additional evidence that the issues being pushed by lobbyists tend to be unrelated to the specific policy concerns of the public. We also find relatively few differences between the policy priorities of low-income and high-income Americans. As a result, the lobbying agenda fails to represent the policy concerns of all broadly defined income groups.

\section{The Case for Equal Representation}

Despite the commonly held view that government is more responsive to wealthier interests, several recent studies suggest that low-income citizens are better represented than one might think. These studies begin from some basic theoretical premises. One is that the re-election incentive ensures that elected government officials need to be responsive to public opinion, at least majority opinion. For example, median voter theories (for example, Downs, 1957) predict that candidates and political parties adopt policy positions to appeal to centrist political values, where most people seem to reside on the political spectrum (Ansolabehere et al, 2006). 
Furthermore, one perspective in mass behavior research contends that politicians learn about the interests of low-income or other disadvantaged groups through elections and public opinion surveys. Some argue that all citizens are able to discern the policies that advance or inhibit their own interests. Several studies argue that people use heuristics, decision-making shortcuts such as party identification, core principles, ideology or endorsements from prominent groups or political figures, to accurately decide which candidates or policies best support their preferences (for example, Popkin, 1994; Lupia and McCubbins, 1998; Arceneaux and Kolodny, 2009; Goren, 2011). These mechanisms enable all citizens, even people in disadvantaged groups, to effectively reveal their policy preferences through the voting booth, public opinion surveys, and other forms of political participation. ${ }^{1}$ Thus, elected officials, who have an incentive to represent the interests of voting majorities, will tend to produce policies that reflect the interests of most voters.

Furthermore, recent studies find that differences in policy opinions between income and other demographic subgroups tend to be small or non-existent, except in the social welfare policy domain. In addition, the policy preferences of different income groups move in tandem over time, even in the social welfare domain (Soroka and Wlezien, 2010; Enns and Wlezien, 2011). Thus, these studies conclude, even if politicians are most responsive to the policy positions of the wealthy, government policy will still likely reflect the preferences of other income groups as well.

As a result, there is evidence that 'dynamic representation', the movement of government policy over time in response to public preferences, occurs fairly equally for rich, poor and middle-income Americans. Government policy outputs are highly responsive to the movement of public opinion over time (Erikson et al, 2002). In particular, changes in government policy respond to changes in public opinion for all income groups, a finding that holds across multiple policy domains (Soroka and Wlezien, 2010). In a similar vein, Baumgartner and colleagues (2009) find that lobbying resources are not a strong predictor of policy change. Similarly, Smith (2000) finds that unified business interests have less influence on public policy than public opinion and elections. ${ }^{2}$ These findings challenge prevailing ideas about the pervasiveness and impact of political inequality in the United States.

However, it is striking that many recent studies comparing citizen policy preferences to government policy outputs do not consider the role of interest groups. In this literature, there is some effort to examine the role of political parties as coalitions of groups that bring certain policy preferences to the government's attention, to the exclusion of other interests (Druckman and Jacobs, 2011; Hussey and Zaller, 2011), but little examination of interest groups (for exceptions, see Bartels, 2008; Gilens, 2011). This is a critical 
omission, for organized interests tend to play a starring role in theories of unequal representation.

\section{The Case for Unequal Representation}

The interest group literature has focused on questions of equal representation for quite some time, particularly spurred by scholarly debates over pluralism and its critics. Schattschneider's (1975, pp. 34-35) colorful observation that 'the flaw in the pluralist heaven is that the heavenly chorus sings with a strong upper-class accent' notes the representational bias in the interest group system. Some demographic groups, such as the poor and unemployed, are not organized. As a result, the interest group community in Washington is skewed in favor of corporate and trade association interests (Schlozman and Tierney, 1986; Baumgartner and Leech, 2001; Schlozman, 2010). Most organized interests represent firms or associations of institutions (such as companies, local governments or universities) rather than associations of individuals (Salisbury, 1984; Schlozman, 2010). Even groups that are designed to represent disadvantaged groups tend to pursue the interests of their wealthier members (Strolovich, 2007).

Organized interests have various ways to make their voices heard by government. Interest groups can spend as much as they can afford on campaign contributions, public relations campaigns and government lobbying while unorganized interests cannot. Assuming that interest groups have some impact on public policy, it is commonly hypothesized that the interest group system introduces bias in the policy process (for example, Olson, 1965; Schattschneider, 1975; Walker, 1991).

Furthermore, the election mechanism whereby the supply of policy matches public demand may have some bugs. Wealthy people are more likely to vote, donate money and volunteer time in politics (Schlozman et al, 1995). Similarly, there is a class bias in membership in voluntary associations (Baumgartner and Walker, 1988; Putnam, 2000). Members of Congress, and senators in particular, tend to be wealthier than the average citizen. Given evidence that elected officials respond more to voters than non-voters (Martin, 2003; Griffin and Newman, 2005; Hajnal, 2010), the ideal of equal representation seems more distant.

Other recent studies argue that the interest group system is an important source of political inequality. For example, Schlozman et al (2012) examine new data on the universe of organized interests in national politics in multiple policy venues. They conclude that despite dramatic expansion of the interest group community, there remains a dearth of organizations representing disadvantaged citizens or the general public. In a study of criminal justice 
policy, Miller (2008) concludes that resource-poor interests are pushed aside when debates reach the state or national levels of government. More generally, Hacker and Pierson (2010) argue that the organizational and resource biases in the interest group system help account for widening income inequality since the 1970s. To complete the circle, Bartels (2008) finds that growing income inequality contributes to unequal political representation in the United States.

Finally, recent evidence challenges the efficiency of low-information rationality. Recent studies indicate that heuristics may lead low-information voters to make 'incorrect' candidate choices, supporting candidates who are not closest to their own policy preferences. Since income and political knowledge are correlated (Althaus, 2003; Bartels, 2008; Lau et al, 2008), those with higher incomes tend to be more knowledgeable about politics and more able to translate their self-interest into policy preferences and voting choices (Gomez and Wilson, 2001; Bartels, 2008). Thus, income is correlated with an ability to make one's voice heard in politics. As a result, several cross-sectional studies find that government policy and politicians are more responsive to elites and high-income constituents than to low- and middle-income citizens (Gilens, 2005, 2009; Jacobs and Page, 2005; Bartels, 2008).

\section{Representation and the Policy Agenda}

Much of the recent literature on policy representation in American politics has compared the policy preferences of the public (or subgroups) to policy outcomes or the roll call votes of legislators, what Jones and colleagues term 'positional' representation (Jones and Baumgartner, 2005; Jones et al, 2009). Although this is a critical area of political representation, policy positions are not the beginning and end of the study of representation in the policy process. For example, Hall (1996) notes that the roll call behavior of legislators does not adequately measure their level of devotion to an issue. Other evidence is needed to measure the intensity of their preferences, to assess how hard they work in crafting legislation and enlisting supporters to get a new policy passed. Similarly, while it is relatively painless for people to reveal their issue positions to a pollster, it is another matter to determine which issues they really care about. As Jones and colleagues (2009) note, studies that compare the ideological preferences of the public with policy outcomes implicitly assume that all issues are equally important to the public, an assumption that usually remains untested.

A critical but limited resource in the policymaking process is attention (Baumgartner and Jones, 1993; Jones, 2001; Jones and Baumgartner, 2005). Government officials have a limited amount of attention they can devote to different policies. Media organizations employ a limited number of journalists to report on policy deliberations to the public. An abundance of issues and 
information must be sifted and prioritized into a small fraction of policies that are considered for action by the government.

Studies of policy representation should also assess whether the policies gaining the attention of government officials are the same policy priorities held by the mass public, and different subgroups of the population. Jones and Baumgartner (2005) denote 'agenda congruence' as the degree to which the public's policy priorities are reflected in the policy agenda in Washington. There is evidence of positive correlations between the policy priorities of the public and the priorities of Congress, as measured by hearings and laws passed, but the correlations are usually less than 0.5 (Jones and Baumgartner, 2005; Jones et al, 2009).

Examining the policy agenda also tends to prompt more explicit consideration of the role of interest groups in the representation equation. Owing to the bias in the lobbying community noted above, it has long been argued that elites have disproportionate influence over the policy agenda (Bachrach and Baratz, 1962; McConnell, 1966; Schattschneider, 1975; Baumgartner, 2010). Several studies find that interest groups have some influence over the policy agenda in Washington (Baumgartner and Jones, 1993; Cobb and Ross, 1997; Berry, 1999). More specifically, there is concern that the class bias in interest group communities may produce a controlled policy agenda that ignores issues that organized interests do not want addressed (Bachrach and Baratz, 1962). This implies that the policy agenda pursued by interest groups may not reflect the issue priorities of the public or of segments of the mass public that suffer from insufficient interest group representation.

Recent studies have compared the public's policy priorities with various measures of government attention and policy outputs. Jones and colleagues (2009) find higher levels of responsiveness to public priorities in agenda-setting stages than in later decision-making stages (such as presidential executive orders or lawmaking). This may lead some to infer that interest group lobbying does not hinder, and may enhance, representation in the policymaking process. However, the policy priorities of organized interests (what we term the 'lobbying agenda') need to be measured and compared with the public's policy priorities to help understand the role of interest groups in agenda-setting. In earlier work, we find evidence that the lobbying agenda is largely unrelated to the public agenda (Baumgartner et al, 2009). We extend that work below by examining additional measures of the public agenda and testing whether different income groups are equally represented in terms of agenda congruence.

\section{Data}

We expand upon previous work to compare the lobbying agenda and the public agenda in the United States for the period from 1998 to 2002. To 
measure the policy priorities of organized interests we first drew a random sample of registered lobbyists in Washington. The sampling frame was based on the reports lobbyists file with Congress each year, with organizations weighted in proportion to their lobbying activity. Thus, groups that reported lobbying on more issues had a greater chance of being selected. We scheduled an interview with a lobbyist for each of the interest groups selected in the sample. At the beginning of each interview we asked the lobbyist to discuss the most recent issue he or she had worked on. Each interview with a newly selected interest group generated one new issue for us to follow. We continued this sampling and interviewing process until we had generated 98 issues, a representative sample of the issues being pushed by lobbyists from 1998 to 2002. Through interviews with other lobbyists and government officials and other public sources, we compiled additional information for each issue, including lobbying activities, interest group resources, issue salience and policy outcomes. $^{3}$

In an ominous sign for public representation, the issues in our lobbying study tend to be rather low in media salience. More than 70 per cent of the lobbying issues were never covered in a network television news story during the study period. Half of the issues were covered in fewer than 16 articles published in the 29 major newspapers indexed by Lexis-Nexis. Only four of the issues were the subject of a television advertising campaign. Nevertheless, the issues identified by lobbyists did receive some attention from government. More than one-third of the issues were the subject of a congressional hearing, and all but six were featured in at least one bill introduced in Congress.

We coded each of the issues in our study in one of the 19 major topic codes and 225 subtopic codes developed by the Policy Agendas Project. The subtopic codes indicate more specific issues within the 19 major policy domains. The distribution of the lobbying agenda is simply indicated by the share of issues in each of the major topic categories. We found that the largest policy domains of the lobbying agenda are health ( 21 per cent), environment (13 per cent), transportation ( 8 per cent), banking and finance ( 7 per cent), national defense ( 7 per cent) and science/technology ( 7 per cent).

We first used data from the Policy Agendas Project to measure the public's issue agenda. ${ }^{4}$ The public opinion data come from Gallup surveys that asked respondents 'What is the most important issue facing the country today?' Gallup conducted 15 national surveys that included the MIP question from the start of 1999 to the end of 2002. The Policy Agendas Project coded the issue categories from the topline results of each survey reported by Gallup into the same 19 major topic areas. Since Gallup, like other survey organizations, recorded multiple issues mentioned by respondents to the MIP question, the issue mentions were normalized so that percentages summed to $100 .^{5}$ The Policy Agendas Project reported annual data on the percentage of issue 
mentions in each of the 19 major topic areas. We averaged the annual measures from 1999, 2000, 2001 and 2002 to create our measure of the public agenda.

In order to examine the issue priorities of citizen subgroups, we need the raw data from public opinion surveys featuring the 'most important problem' question. However, we are unable to get access to many of the relevant Gallup survey data for the 1999-2002 study period. Instead, we examine public opinion data from two other sources. We used data from these surveys to validate our original findings regarding the public's policy priorities. One of our data sources is the Pew Research Center, which included the MIP question in five national surveys conducted between January of 1999 and December of 2002. Pew used the same question wording as Gallup and also recorded multiple issue mentions from respondents. We coded the MIP issue categories from the Pew polls into the 19 major topic areas as the Policy Agendas Project. We also followed the same method as used by the Policy Agendas Project (Feeley et al, 2001) to compute a normalized average of responses to the MIP question across the five Pew polls.

To examine subgroups of the public, we obtained the respondent-level data for all five Pew surveys (conducted in June 1999, August 1999, February 2001, May 2001 and March 2002). We merged the data files, producing a sample of 4768 respondents who answered the MIP question. We divided the sample into three income categories: low (under US\$35 000), medium (between $\$ 35000$ and $\$ 75000)$ and high (\$75000 and above).

Our second source of public opinion data are the American National Election Studies (ANES), which included a most important problem question in the 1998 post-election surveys and a randomly selected half sample of the 2000 pre-election survey. ANES did not include the MIP question in its 2002 post-election survey. The ANES MIP question wording is slightly different than that used by Pew and Gallup. The ANES question is 'What do you think are the most important problems facing this country?' Since ANES asks for multiple mentions rather than a single mention, the ANES surveys produce more issue mentions per respondent (up to five) than Gallup or Pew. For this analysis, we just examine the first issue mentioned by the respondent. ${ }^{6}$

We merged the two ANES data files, producing a sample of 2123 who answer the MIP question. We coded the MIP responses into the 19 major topic areas developed by the Policy Agendas Project. In addition, ANES codes responses to the MIP question in much more fine-grained categories than the other two polling organizations. This allows us to also code the ANES MIP responses into the subtopic categories created by the Policy Agendas Project. Finally, we split the ANES sample into the same three income categories noted above. We acknowledge that even though the public opinion measures ask about the most important problems 'facing the country', survey respondents may mention issues involving the national, state or local levels of government. 
In contrast, our measure of the lobbying agenda is based solely on interest groups in Washington. This may account for some of the discrepancy between our measures of the lobbying agenda and the public agenda. We discuss this issue more in the conclusion.

\section{Results}

We first compare the lobbying agenda to the broad policy priorities of the public. Figure 1 compares the distribution of issues in the lobbying agenda with the summary public opinion data on the MIP question from the Gallup and Pew surveys. ${ }^{7}$ As the figure shows, using either public opinion measure, the policy priorities of the public bear little resemblance to the policy priorities of organized interests. From 1999 to 2002, the domains that occupied the most space on the lobbying agenda were health care, the environment, transportation, finance, defense and science and technology, whereas the most important

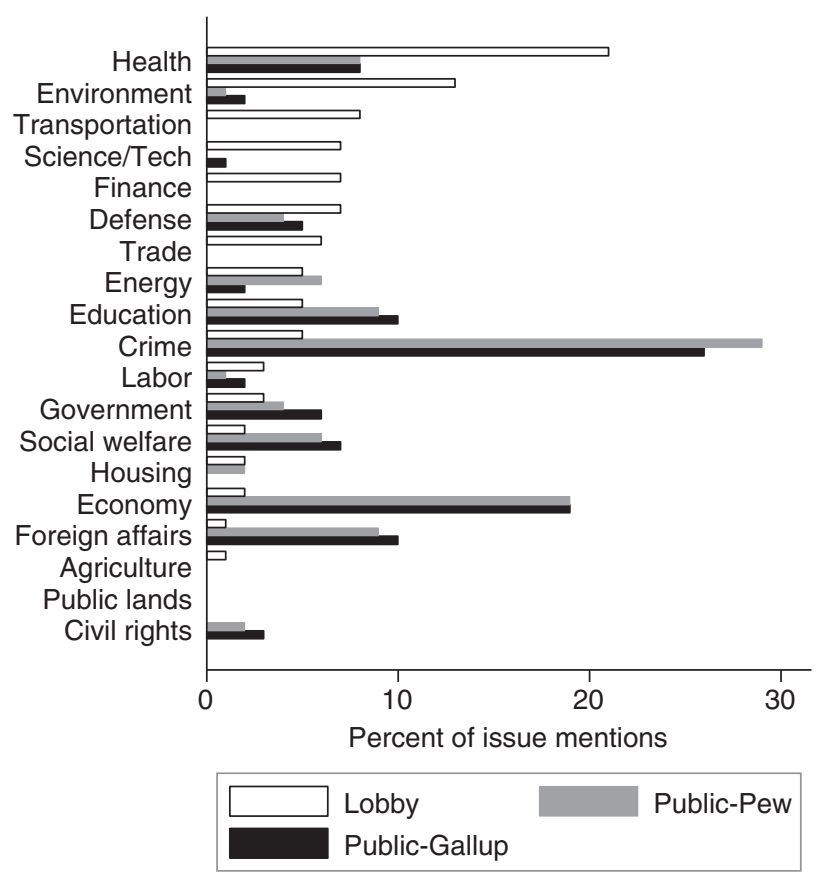

Figure 1: The lobbying agenda versus the public agenda, 1999-2002 (Gallup and Pew).

Note: The figure shows the percentage of lobbying cases compared with the average responses to the poll question 'What is the most important problem facing the country today? 
issues for the public were crime, the economy, education, foreign affairs, health care and social welfare. The Pew polling data produces almost the exact same distribution of the relative important of different policy domains as the Gallup survey data (the correlation between the Gallup and Pew 'most important problem' distributions is 0.98 ). However, there is no correlation between either measure of the policy priorities of the public and the share of the agenda space accorded each policy domain in terms of lobbying activity $(r=-0.01$ in both comparisons).

Figure 2 shows a similar comparison between the lobbying and public agendas, this time featuring the Gallup and ANES public opinion measures. The ANES data also show a mismatch between the public agenda and the lobbying agenda. In fact, the correlation between the ANES MIP issue distribution and the lobbying agenda is more negative $(r=-0.12)$ than what is observed with the Gallup and Pew MIP measures.

The issue distribution in the ANES MIP measure is positively associated with the Gallup measure $(r=0.90)$ but not as strongly as the Pew MIP measure. This is likely due to the timing of the ANES surveys (in the fall of

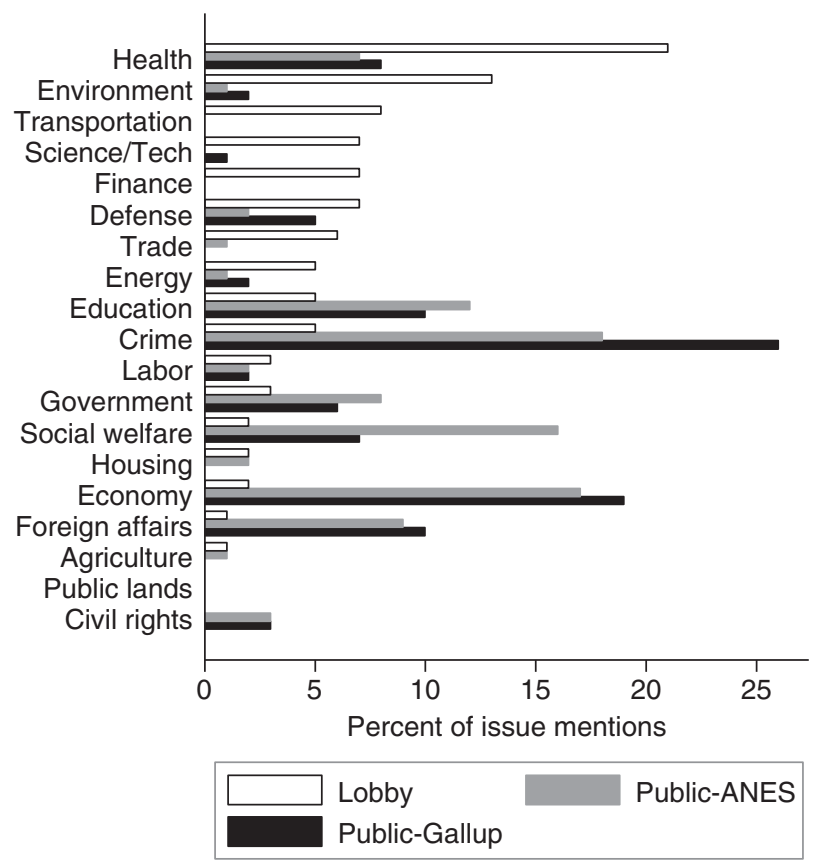

Figure 2: The lobbying agenda versus the public agenda, 1999-2002 (Gallup and ANES). Note: The figure shows the percentage of lobbying cases compared with the average responses to the MIP question in Gallup and ANES surveys. 
a general election year only) and the fact that the ANES sample does not include any respondents interviewed after 2000. The absence of any post-9/11 surveys in the ANES sample may help explain why defense and crime receive fewer mentions when compared with the Gallup data. The ANES sample also relies heavily on the 1998 survey, which took place while the Clinton impeachment scandal was featured in many congressional campaigns. This accounts for the higher share of government operations mentions in the ANES sample. Regardless of which public opinion measure is used, we find no congruence between the public agenda and the lobbying agenda.

If the lobbying agenda and public agenda are unrelated, which one more closely corresponds to other measures of agenda setting? We examine two policymaking channels, congressional hearings and State of the Union speeches, for the same 1999-2002 time period. For both channels we use data from the Policy Agendas Project to determine the share of each agenda devoted to the same 19 policy domains described above. ${ }^{8}$ Since major presidential speeches are primarily crafted for a public audience (Kernell, 2007), we expect to find a stronger correlation between the public agenda and the policy agenda in State of the Union speeches. Table 1 reports the correlations between the two policy channel measures and our measures of the lobbying and public agenda. The share of the agenda space accorded each policy domain in congressional hearings is more closely correlated with the lobbying agenda $(r=0.24)$ than with the public agenda $(r=0.08)$. For the period of our study, hearings held in the people's Congress seem to correspond with interest group priorities more than public priorities. However, the policy agenda in State of the Union addresses is strongly related to public opinion $(r=0.65)$ but not to the lobbying agenda $(r=-0.03)$. Thus, the State of the Union appears to be an institution for channeling public concerns, rather than interest group priorities.

Jones and Baumgartner (2005) observe that public attention tends to be concentrated on a few policy priorities at a time. Survey responses to the MIP question tend to cluster in a small number of policy domains, often national security and the economy. In contrast, they find that Congress is able to devote

Table 1: Correlations of agenda measures with lobbying and public priorities

\begin{tabular}{lcr}
\hline Priority measure & \multicolumn{2}{c}{ Policy channel } \\
\cline { 2 - 3 } & Hearings & State of the union \\
\hline Lobby agenda & 0.24 & -0.03 \\
Public - MIP & 0.08 & 0.65
\end{tabular}

Note: Pearson correlation coefficients. 
attention to many issues at the same time. The size and staff capacity of Congress, and the division of labor formalized by the committee system, mean that Congress can juggle more issues. We find similar evidence in characterizing the public agenda, and the lobbying agenda more closely resembles the legislative agenda in terms of issue diversity. Figures 1 and 2 show that 7 of the 19 policy domains receive no mention in at least one of the public opinion measures during a 4-year period. The 98 issues on the lobbying agenda during the same period exclude just 2 of the 19 policy domains (public lands and civil rights). ${ }^{9}$ The lobbying agenda, which reflects the pluralism of the interest group system, more closely resembles the legislative agenda in juggling many issues.

A recent study of representation by Jones et al (2009) compared the public agenda with the issue distribution observed at various stages of the policymaking process, including congressional hearings, bills, laws, Supreme Court decisions, executive orders and media coverage. On average, they find positive correlations between the public agenda and each policymaking channel. Our finding of no correlation between the public agenda and the lobbying agenda suggests there is less representation in the lobbying system than any of the other policymaking channels, not a surprising result given the representational bias in lobbying groups. Jones and colleagues also find that public priorities tend to be better represented at agenda-setting stages of the policy process than at later decision-making stages. They reason that this is due to fewer institutional barriers to government action at the agenda-setting stage. Again, we find that the lobbying agenda does not reflect broad public priorities. Thus, representation of the public's policy priorities at the agenda-setting stage of government activity occurs in spite of, not because of, organized interests.

We next consider whether the lobbying agenda more closely reflects the policy priorities of smaller issue publics. Many subgroups might be compared in this manner. Since several recent studies examine the positional representation different income groups, our first step in this area is to examine whether there is evidence of differential agenda representation for different income groups in the public. Using the Pew and ANES survey data, we divide the samples into three income groups, those below $\$ 35000$ (denoted as low income), those between $\$ 35000$ and $\$ 75000$ (medium income), and those at or above $\$ 75000$ (high income).

Figure 3 plots the distribution of policy priorities in the Pew data by income group for the 1999-2002 study period. There does not appear to be much difference between the broad issue priorities of low-income and high-income Americans. Domains that are mentioned as important by one income group tend to be important to the other income groups as well. Domains that are not mentioned by one income group are also ignored by other income groups. For a few domains there are modest differences in the frequency with which they are mentioned by different income groups. The low-income group rates 


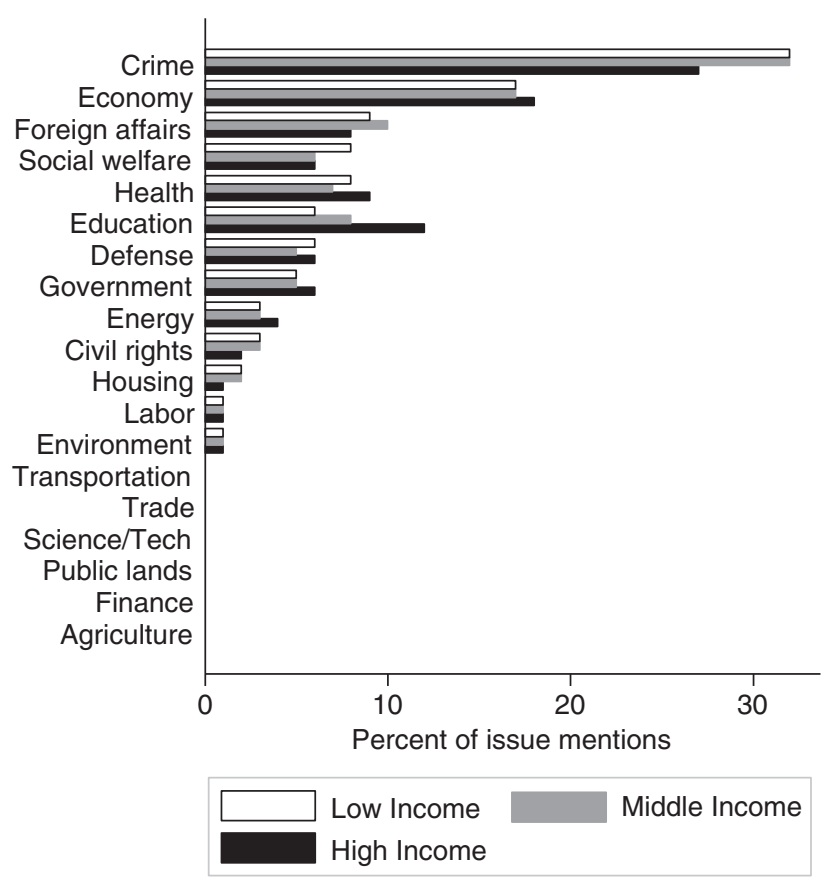

Figure 3: The public agenda by income group, 1999-2002 (Pew).

crime and social welfare as somewhat more important domains than the high-income group, whereas high-income respondents were more likely to mention education as an important issue. Given the size of the sample, these group differences are statistically significant while modest in substance.

The similarities in the policy distributions by income group in Figure 3 are more numerous than the differences. As a result, the policy agenda for each income group is similarly unrelated to the lobbying agenda for this period. The correlation between the lobbying agenda and the public agenda is -0.02 for low-income respondents, -0.04 for middle-income respondents and 0.03 for high-income respondents. ${ }^{10}$

For a finer comparison of the lobbying and public agenda, we take advantage of the detailed coding of the MIP responses in the ANES survey data. We examine policy domains that received at least a modest share of responses in the ANES data, so that the sample is still large enough to compare income groups. Within each domain, we then compare the public agenda with the lobbying agenda using the more specific subtopic codes developed by the Policy Agendas Project. ${ }^{11}$ The results, presented in Table 2, show that the disparity between the lobbying agenda and the public agenda is more 
Table 2: Subtopic comparison of public's policy priorities to lobby agenda by income level

\begin{tabular}{|c|c|c|c|c|}
\hline \multirow[t]{2}{*}{ Domain } & \multicolumn{3}{|c|}{ Income } & \multirow{2}{*}{$\frac{\text { Lobby }}{\text { Agenda }}$} \\
\hline & Low & Medium & High & \\
\hline \multicolumn{5}{|l|}{ Economy } \\
\hline General economic issues & 32 & 40 & 37 & 0 \\
\hline Unemployment & 32 & 24 & 17 & 0 \\
\hline National budget and debt & 17 & 15 & 30 & 0 \\
\hline Tax policy & 9 & 13 & 11 & 100 \\
\hline Other economic issues & 10 & 8 & 5 & 0 \\
\hline \multicolumn{5}{|l|}{ Health } \\
\hline Comprehensive health reform & 92 & 95 & 97 & 5 \\
\hline Provider and insurance payment & 0 & 0 & 0 & 36 \\
\hline Other health issues & 8 & 5 & 3 & 59 \\
\hline \multicolumn{5}{|l|}{ Social welfare } \\
\hline General social welfare issues & 11 & 12 & 23 & 0 \\
\hline Poverty & 47 & 25 & 27 & 0 \\
\hline Elderly issues & 42 & 62 & 50 & 0 \\
\hline Assistance to the disabled & 0 & 0 & 0 & 100 \\
\hline \multicolumn{5}{|l|}{ Crime } \\
\hline Family issues & 31 & 47 & 58 & 0 \\
\hline Riots and crime prevention & 34 & 31 & 16 & 0 \\
\hline Drugs & 22 & 9 & 14 & 0 \\
\hline Police and guns & 3 & 6 & 7 & 40 \\
\hline Criminal and civil code & 0 & 0 & 0 & 40 \\
\hline Court administration & 0 & 0 & 0 & 20 \\
\hline Other crime issues & 10 & 7 & 5 & 0 \\
\hline \multicolumn{5}{|l|}{ International affairs } \\
\hline General international issues & 44 & 49 & 31 & 0 \\
\hline Middle East & 32 & 29 & 31 & 0 \\
\hline Foreign aid & 19 & 12 & 0 & 100 \\
\hline International finance & 0 & 5 & 23 & 0 \\
\hline Other international issues & 5 & 5 & 15 & 0 \\
\hline
\end{tabular}

The table shows the percentage of lobbying issues within certain domains compared with the percentage of income subgroups naming the same issues in response to the MIP question in ANES surveys.

extensive. In addition, we find additional evidence of differences in the policy priorities of low-income and high-income respondents in some domains that appear consistent with their economic interests.

On economic issues, the public most frequently mentioned general concerns (for example, jobs or recession), unemployment, and the national debt. 
High-income respondents attached more importance to the national debt, whereas low-income respondents more frequently mentioned unemployment as an important economic issue, differences that are statistically significant $(P<0.05)$. In contrast, all seven economic issues on the lobbying agenda dealt with tax policy (for example, estate tax, excise tax, interest expense taxes, sales taxes, the tax status of stock options, tax rates for computer depreciation and taxes on government pensions), a subtopic rarely mentioned by respondents of all income levels. Thus, the economic issues pursued by the lobbyists in our sample generally did not correspond with the priorities of Americans who mentioned economic issues as the most important problems facing the country.

Health care stood out as the largest domain on the lobbying agenda. Among survey respondents in the health domain, more than nine of every 10 in each income group mentioned comprehensive health reform as an important issue. Although two health issues in the lobbying agenda involved systemic reforms of the health-care system, most of the lobbying on health issues involved other concerns. More than one-third of the health issues on the lobbying agenda involved payments for health-care providers or insurance coverage for particular treatments, issues that were not specifically mentioned by survey respondents. More than half of the health issues on the lobbying agenda involved other issues, such as research and development, regulating the drug industry, and hospital facilities, that were rarely mentioned by respondents of any income level.

Crime was the most frequently mentioned policy domain on the public agenda. The crime issues most frequently mentioned by the public included family issues (mentioned more by high-income respondents), as well as drugs and crime prevention (mentioned most often by low-income respondents). There was no lobbying activity on those crime issues. Instead, the crime portion of the lobbying agenda involved police and gun control, changes in criminal and civil code, and court administration, issues that were rarely mentioned by the public.

In the social welfare policy domain, poverty was the most frequently mentioned issue for low-income respondents. Elderly issues were also frequently mentioned by the public. However, these issue concerns were not part of the lobbying agenda. The one social welfare issue on the lobbying agenda involved assistance to the disabled, an issue not mentioned by the survey respondents. Within the domain of international affairs, the one issue on the lobbying agenda dealt with foreign aid, an issue not mentioned very frequently by the public. Important public concerns in the realm of foreign affairs most often referred to the Middle East and general concerns (for example, war and peace). Again, these topics did not appear on the lobbying agenda.

When we look more closely within policy domains, there is further evidence that the lobbying agenda does not reflect the public's policy priorities. Even when Americans and lobbyists refer to the same policy domain as a priority, they frequently mean different types of issues within that domain. It is possible 
that issues receiving lobbying attention may have satisfied some of the general concerns expressed by the public in those policy domains, but that remains an untested hypothesis.

\section{Conclusion}

It is important for studies of policy representation to consider the policy priorities of the public in addition to the issue preferences of the public. For representation to occur it is necessary for the government to address the policy concerns of the public. We hope this will lead to a closer examination of other stages of the policymaking process and the role of interest groups in the representation equation. When it comes to the policy agenda, we find that the bias in the interest group system means that the issues pushed by lobbyists generally do not correspond to the policy priorities of the public. We find no correlation between the lobbying agenda and the public agenda, using multiple measures of public opinion. Even when public concerns and lobbying activity share the same policy domain, the specific issues advanced by lobbyists tend to be different from the specific policy concerns of the public. Future studies of political inequality and representation would be wise to examine the role of organized interests in agenda setting. In particular, it is important to consider where lobbyists are devoting much of their attention (for example, see Baumgartner et al, 2011).

We also find relatively few differences between the policy priorities of lowincome and high-income publics, although when differences emerge they tend to reflect the competing economic interests of wealthy and poor Americans. We divided the survey samples into fairly broad income categories. In particular, the high-income group (\$75000 and above in annual income) encompasses a wide range of wealth. It may be that those advantaged by the interest group system are a small enough slice of the public that it is difficult to isolate them in survey data. For example, Page (2009) notes that the top one-tenth of 1 per cent in the income distribution, though they control a lot of wealth, comprise such a small number of people that they have not been reliably identified in sample surveys. In addition, it makes sense to move beyond income and examine other issue publics. Some have begun to examine the political attitudes of lobbyists (Kersh, 2002; Koger and Victor, 2009). Studies of representation might also do more to measure the policy priorities and preferences of corporations and other institutions that dominate the interest group system.

We believe a key reason for the extremely weak correlation between the lobbying agenda and the public agenda is due to the representational biases in the interest group system. However, there are some alternative explanations worth considering. One explanation involves the federal nature of 
American government. Much policymaking in domains such as crime and education takes place in state and local governments. As a result, those domains may occupy a smaller portion of our measure of the lobbying agenda because we do not measure lobbying at the state and local level. This is an important explanation, although we do not have the data to test it. Although federalism can explain some of the results in this study, it does not eliminate representational bias as an explanation. For example, crime would need to account for 25 per cent of interest group lobbying at the state and local level to match the public's concern about crime in our study period, something we believe is unlikely. Miller's (2008) study of lobbying on crime policy at different levels of government finds less representational bias at the local level, but she finds that unequal representation in national politics have substantially distorted crime policy in the United States.

Given the bias in the interest group system, it is not surprising that the lobbying agenda poorly reflects public priorities. We find that most of the issues on the lobbying agenda receive little attention from the media, and thus receive little attention from the public. The lack of public attention did not prevent government action on the issues in the lobbying agenda. While the status quo was the likely outcome after observing the issues in the lobbying study for 4 years, when policy change occurred it was frequently significant, rather than incremental. In addition, policy change was largely unrelated to the salience of the lobbying issues (Baumgartner et al, 2009).

This is a concern for policy representation given that government tends to be more responsive to the public on more salient issues when the public is watching (Arnold, 1990; Epstein and Segal, 2000; Burstein, 2003). Very few of the issues in our lobbying study were the subject of questions in a national survey, so public opinion was not a significant factor in government deliberations on these issues. More to the point, among the lobbyists we interviewed, the mass public was very rarely mentioned as an obstacle to getting their preferred policy outcome. They more frequently noted organized opposition or a lack of attention from government officials as the main impediments to their policy goals. This is not to suggest that interest groups act with impunity or that the public has no impact on government decision-making. However, studies of representation in the policymaking process need to carefully examine the role of interest groups and the lobbying agenda.

\section{Notes}

1 For a review of this literature, see Niemi et al (2011, Chapter 5).

2 Also, see Smith (2010).

3 For more details on the research methodology, see Baumgartner et al (2009). The complete list of issues, as well as additional documentation and data are available at lobby.la.psu.edu/. 
4 The data from the Policy Agendas Project were originally collected by Frank R. Baumgartner and Bryan D. Jones, with the support of the National Science Foundation.

5 See Feeley et al (2001) for more details on the Policy Agendas Project MIP coding.

6 The first issue mentioned is likely the one at the 'top of the head' of the respondent (Zaller, 1992). In addition, less than 20 per cent of Pew respondents provide multiple issues in response to the MIP question. A larger portion of ANES respondents provide multiple mentions. In ANES data, the distribution of issues in the second and third mentions is similar to what we find with the first response mentioned.

7 Part of Figure 1 previously appeared in Baumgartner et al (2009, p. 258).

8 The data on hearings and State of the Union speeches can be found in Baumgartner et al (2009, p. 17).

9 Of the 98 lobbying issues, one environmental issue (logging in national forests) involved public lands and one crime issue (criminal justice reform) had a strong civil rights component.

10 With the ANES data, we also find that the lobbying agenda is not positively associated with the policy priorities of any income group. The ANES data reveal less consistency in policy priorities across income groups than the Pew data. In the ANES data, low-income respondents are more likely than high-income respondents to mention crime, social welfare, foreign affairs and government operations as important issues, whereas high-income respondents are more likely to cite education and health care as important issues.

11 We exclude two policy domains that received a substantial number of mentions in the ANES surveys. One is education, where the survey responses only referred to general education concerns, not specific topics that could be compared with the education issues in the lobbying agenda. The second domain is government operations. Roughly, one-third of the government operations mentions in the ANES survey referenced the Clinton impeachments scandal. The impeachment trial was over by the start of 1999 , and there was no lobbying on that issue in our study.

\section{References}

Althaus, S.L. (2003) Collective Preferences in Democratic Politics. New York: Cambridge University Press.

Ansolabehere, S., Rodden, J. and Snyder Jr, J.M. (2006) Purple America. Journal of Economic Perspectives 20(2): 97-118.

Arceneaux, K. and Kolodny, R. (2009) Educating the least informed: Group endorsements in a grassroots campaign. American Journal of Political Science 53(4): 755-770.

Arnold, R.D. (1990) The Logic of Congressional Action. New Haven, CT: Yale University Press.

Bachrach, P. and Baratz, M. (1962) Two faces of power. American Political Science Review 56(4): 947-952.

Bartels, L.M. (2008) Unequal Democracy. Princeton, NJ: Princeton University Press.

Baumgartner, F.R. (2010) Interest groups and agendas. In: L. Sandy Maisel and J.M. Berry (eds.), The Oxford Handbook of American Political Parties and Interest Groups. New York: Oxford University Press, pp. 519-533.

Baumgartner, F.R., Berry, J.M., Hojnacki, M., Kimball, D.C. and Leech, B.L. (2009) Lobbying and Policy Change: Who Wins, Who Loses, and Why. Chicago, IL: University of Chicago Press.

Baumgartner, F.R. and Jones, B.D. (1993) Agendas and Instability in American Politics. Chicago, IL: University of Chicago Press.

Baumgartner, F.R., Larsen-Price, H.A., Leech, B.L. and Rutledge, P. (2011) Congressional and presidential effects on the demand for lobbying. Political Research Quarterly 64(1): 3-16. 
Baumgartner, F.R. and Leech, B.L. (2001) Interest niches and policy bandwagons: Patterns of interest group involvement in national politics. Journal of Politics 3(4): 1191-1213.

Baumgartner, F.R. and Walker Jr, J.L. (1988) Survey research and membership in voluntary association. American Journal of Political Science 32(4): 908-928.

Berry, J.M. (1999) The New Liberalism: The Rising Power of Citizen Groups. Washington DC: Brookings Institution.

Burstein, P. (2003) The impact of public opinion on public policy: A review and an Agenda. Political Research Quarterly 56(1): 29-40.

Cobb, R.W. and Ross, M.H. (eds.) (1997) Cultural Strategies of Agenda Denial: Avoidance, Attack, and Redefinition. Lawrence, KS: University Press of Kansas.

Downs, A. (1957) An Economic Theory of Democracy. New York: Harper and Row.

Druckman, J.N. and Jacobs, L.R. (2011) Segmented representation: The Reagan white house and disproportionate responsiveness. In: P.K. Enns and C. Wlezien (eds.), Who Gets Represented? New York: Oxford University Press.

Enns, P.K. and Wlezien, C. (eds.) (2011) Who Gets Represented? New York: Russell Sage Foundation.

Epstein, L. and Segal, J.A. (2000) Measuring issue salience. American Journal of Political Science 44(1): 66-83.

Erikson, R.S., MacKuen, M.B. and Stimson, J.A. (2002) The Macro Polity. Cambridge, UK: Cambridge University Press.

Feeley, T.J., Jones, B.D. and Larsen, H. (2001) Public Agenda: Annualized Most Important Problem Polling Data, 1939-2001. Seattle, WA: University of Washington, (Portions of this data originally compiled by the Gallup Organization).

Gilens, M. (2005) Inequality and democratic responsiveness. Public Opinion Quarterly 69(5): 778-796.

Gilens, M. (2009) Preference gaps and inequality in representation. Political Science and Politics 42(2): 335-341.

Gilens, M. (2011) Policy consequences of representational inequality. In: P.K. Enns and C. Wlezien (eds.), Who Gets Represented? New York: Oxford University Press.

Gomez, B.T. and Wilson, J.M. (2001) Political sophistication and economic voting in the American electorate: A theory of heterogeneous attribution. American Journal of Political Science 45(4): 899-914.

Goren, P. (2011) Political sophistication and policy reasoning: A reconsideration (updated). In: R. Niemi, H.F. Weisberg and D.C. Kimball (eds.), Controversies in Voting Behavior, 5th edn. Washington DC: CQ Press.

Griffin, J.D. and Newman, B. (2005) Are voters better represented? Journal of Politics 67(4): $1206-1227$.

Hacker, J.S. and Pierson, P. (2010) Winner-Take-All Politics: How Washington Made the Rich Richer - and Turned its Back on the Middle Class. New York: Simon \& Schuster.

Hajnal, Z. (2010) America's Uneven Democracy: Race, Turnout, and Representation in City Politics. Cambridge, UK: Cambridge University Press.

Hall, R.L. (1996) Participation in Congress. New Haven, CT: Yale University Press.

Hussey, W. and Zaller, J. (2011) Who do parties represent? In: P.K. Enns and C. Wlezien (eds.), Who Gets Represented? New York: Oxford University Press.

Jacobs, L.R. and Page, B.I. (2005) Who influences U.S. foreign policy? American Political Science Review 99(1): 107-123.

Jacobs, L.R. and Skocpol, T. (eds.), (2005) Inequality and American Democracy. New York: Russell Sage Foundation.

Jones, B.D. (2001) Politics and the Architecture of Choice. Chicago, IL: University of Chicago Press. 
Jones, B.D. and Baumgartner, F.R. (2005) The Politics of Attention. Chicago, IL: University of Chicago Press.

Jones, B.D., Larsen-Price, H. and Wilkerson, J. (2009) Representation and American governing institutions. Journal of Politics 71(1): 277-290.

Kelly, N.J. (2009) The Politics of Income Inequality in the United States. New York: Cambridge University Press.

Kernell, S. (2007) Going Public: New Strategies of Presidential Leadership, 4th edn. Washington DC: CQ Press.

Kersh, R. (2002) Washington lobbyists as political actors. In: A.J. Cigler and B.A. Loomis (eds.), Interest Group Politics, 6th edn. Washington DC: CQ Press.

Koger, G. and Victor, J.N. (2009) Polarized agents: Campaign contributions by lobbyists. Political Science \& Politics 42(3): 485-488.

Lau, R.R., Andersen, D.J. and Redlawsk, D.P. (2008) An exploration of correct voting in recent U.S. presidential elections. American Journal of Political Science 52(2): 395-411.

Lupia, A. and McCubbins, M.D. (1998) The Democratic Dilemma: Can Citizens Learn What They Need to Know? Cambridge: Cambridge University Press.

Martin, P.S. (2003) Voting's rewards: Voter turnout, attentive publics, and congressional allocation of federal money. American Journal of Political Science 47(1): 110-127.

McConnell, G. (1966) Private Power and American Democracy. New York: Knopf.

Miller, L.L. (2008) The Perils of Federalism: Race, Poverty and the Politics of Crime Control. New York: Oxford University Press.

Niemi, R.G., Weisberg, H.F. and Kimball, D.C. (eds.), (2011) Controversies in American Voting Behavior, 5th edn. Washington DC: CQ Press.

Olson Jr, M. (1965) The Logic of Collective Action. Cambridge, MA: Harvard University Press.

Page, B.I. (2009) Review symposium: Perspectives on Unequal Democracy. Perspectives on Politics 7(1): 148-151.

Picketty, T. and Saez, E. (2003) Income inequality in the United States. Quarterly Journal of Economics 118(1): 1-39.

Popkin, S.L. (1994) The Reasoning Voter: Communication and Persuasion in Presidential Campaigns, 2nd edn. Chicago, IL: University of Chicago Press.

Putnam, R.D. (2000) Bowling Alone: The Collapse and Revival of American Community. New York: Simon \& Schuster.

Salisbury, R.H. (1984) Interest representation: The dominance of institutions. American Political Science Review 78(1): 64-76.

Schattschneider, E.E. (1975) The Semisovereign People: A Realist's View of Democracy in America. Fort Worth, TX: Harcourt Brace Jovanovich College Publishers, (originally published in 1960).

Schlozman, K.L. (2010) Who sings in the heavenly chorus? The shape of the organized interest system. In: L.S. Maisel and J.M. Berry (eds.), The Oxford Handbook of American Political Parties and Interest Groups. New York: Oxford University Press, pp. 425-450.

Schlozman, K.L. and Tierney, J. (1986) Organized Interests and American Democracy. New York: Harper \& Row.

Schlozman, K.L., Verba, S. and Brady, H.E. (1995) Voice and Equality: Civic Volunteerism and American Politics. Cambridge, MA: Harvard University Press.

Schlozman, K.L., Verba, S. and Brady, H.E. (2012) Unequal Advocacy: Political Voice and the Promise of American Democracy. Princeton, NJ: Princeton University Press.

Smith, M.A. (2000) American Business and Political Power: Public Opinion, Elections, and Democracy. Chicago, IL: University of Chicago Press.

Smith, M.A. (2010) The mobilization and influence of business interests. In: L.S. Maisel and J.M. Berry (eds.), The Oxford Handbook of American Political Parties and Interest Groups. New York: Oxford University Press, pp. 451-467. 
Soroka, S.N. and Wlezien, C. (2010) Degrees of Democracy: Politics, Public Opinion, and Policy. New York: Cambridge University Press.

Strolovich, D.Z. (2007) Affirmative Advocacy: Race, Class and Gender in Interest Group Politics. Chicago, IL: University of Chicago Press.

Walker Jr, J.L. (1991) Mobilizing Interest Groups in America. Ann Arbor, MI: University of Michigan Press.

Zaller, J.R. (1992) The Nature and Origins of Mass Opinion. New York: Cambridge University Press. 